\title{
PARTIAL 18 TRISOMY SYNDROME RESULTING FROM PATERNAL 6/18 RECIPROCAL TRANSLOCATION ${ }^{1}$
}

\author{
Koichi Fukuhara, Kyoko Fukuhara, Masahiro Mino, \\ Tomoichi Kusunoki, Shinichi Misawa,* Masuji Morita** \\ and Tatsuo ABE**
}

\begin{abstract}
Department of Pediatrics, *Third Department of Internal Medicine,
**Department of Preventive Medicine, Kyoto Prefectural University of Medicine, Kyoto
\end{abstract}

Summary A female infant with distal $18 \mathrm{q}$ trisomy, confirmed by G- and Q-banding was reported. Her karyotype was $46, \mathrm{XX},-6,+\operatorname{der}(6), \mathrm{t}(6 ; 18)$ $(18 \mathrm{qter} \rightarrow 18 \mathrm{q} 21:: 6 \mathrm{p} 24$ or $25 \rightarrow$ 5pter)pat. She had the following clinical stigmata: hypertelorism, coloboma, bulbous nose with shallow nasal bridge, high arched palate, small chin, folds of redundant nuchal skin, hemangioma and limited abduction of the hip joints.

\section{INTRODUCTION}

In addition to the regular type of 18 trisomy (Edwards et al., 1960), cases with trisomy for the long arm of chromosome 18 resulting from reciprocal translocation have been sporadically reported. Among them there are two types of $18 \mathrm{q}$ trisomy. One type is accompanied by typical features of 18 trisomy such as a prominent occiput, clenched fists with overlapping fingers, a narrow pelvis and rocker bottom feet (Hecht et al., 1963; Rohde et al., 1963; Gagnon et al., 1963; Uchida et al., 1964; Freiman and Wilton, 1967; Meyer-Robisch and Schwanitz, 1967; Gleissner et al., 1970; Chesler et al., 1970; Eriksson et al., 1971; Cohen et al., 1972; Goto et al., 1973). The other type is not accompanied by them (Van Wijk et al., 1961; Brodie and Dallaire, 1962; Valdmanis et al., 1967; Rudd and Lamarche, 1971; Orye and Van Caster, 1972; Jenkins et al., 1974). Recent banding techniques have enabled us to identify the trisomic part of each case. We report a case of distal $18 \mathrm{q}$ trisomy $(18 \mathrm{qter} \rightarrow \mathrm{q} 21)$ due to a paternal $6 / 18$ translocation, whose clinical manifestations were much milder than those of regular 18 trisomy.

Received October 25, 1978

1 Supported in part by the Ministry of Health and Welfare, and the Ministry of Education, Science, and Culture of Japan in a grant given to Dr. T. Abe.

*Address of the first author: Department of Pediatrics, Kyoto Prefectural University of Medicine, Kamikyo-ku, Kyoto 602, Japan. 


\section{CASE REPORT}

The proposita was born as a first child of a 26 -year-old mother and a 29 -yearold father. There was consanguinity on the mother's side, i.e. the mother's parents were second cousins. The mother had no miscarriages but 3 siblings of the father were stillborn. The pregnancy was uneventful, however, the delivery was induced with oxytocin at 39 weeks of gestation because of the contracted pelvis. Apgar score was 5 and resuscitation was necessary. At birth, weight was $2,700 \mathrm{~g}$, body length $43 \mathrm{~cm}$ and head circumference $32.5 \mathrm{~cm}$. She had frequent episodes of cyanotic attacks and mild generalized tonic convulsions during neonatal period. She could not suck milk adequately and the rest of the required amount was administered through a nasogastric tube. When she was transferred to our hospital at 74
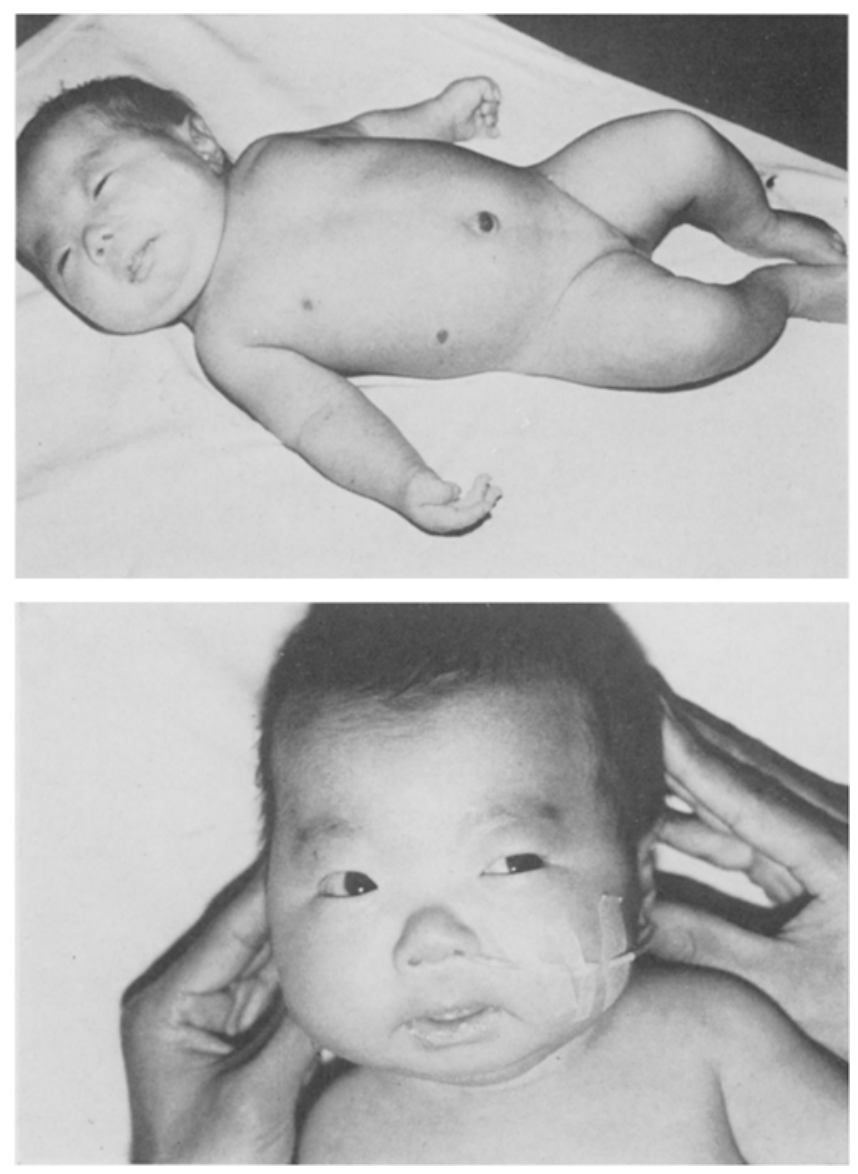

Fig. 1. The proposita. 


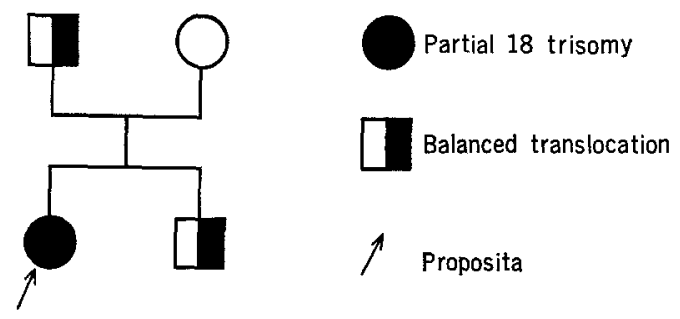

Fig. 2. Pedigree of the family.

days of age, she weighed 4,080 g. Her abnormal findings included: slight hypertelorism, coloboma of the left iris, atrophy of uveae and optic nerves, bulbous nose with shallow nasal bridge, high arched palate, small chin, husky crying voice, folds of redundant nuchal skin, hemangioma in the right abdominal flank and limited abduction of the hip joints (Fig. 1). Dermatoglyphics were unfortunately not available. The pedigree of the family is shown in Fig. 2.

\section{Laboratory findings}

Routine blood count, urinalysis and feces were normal. Hypogamma-globulinemia was demonstrated by electrophoresis. Electrocardiogram and electromyogram were within normal limits. Roentgenogram of the skull showed shallow sella turcica. Roentgenogram of the chest, the abdomen and the extremities revealed no abnormalities.

\section{Clinical course}

She showed slight failure to thrive and developmental delay. She had stridor and developed frequent respiratory distress because of glossoptosis, especially while she was asleep. She finally died of such an apneic attack at 195 days of age. Autopsy permission was not granted.

\section{Cytogenetic findings}

Cytogenetic studies were performed on blood cells from the proposita and her parents. Metaphases were obtained by the standard leukocyte culture technique. The Q-staining method was that described by Caspersson et al.(1970) with a minor modification (Misawa et al., 1975). As a G-band technique, trypsin-Giemsa was employed with modifications (Abe et al., 1976). Conventional Giemsa staining revealed that the proband's karyotype was $46, \mathrm{XX}, \mathrm{Cp}+$. The same marker chromosome was found in the father. Q- and G-banded karyotypes of the father revealed a reciprocal translocation between chromosomes 6 and 18 with break points at 6 p24 or 25 and $18 \mathrm{q} 21$, respectively (Fig. 3). Partial karyotypes from the proband and her father are shown in Fig. 4. Therefore, patient's karyotypes could be described as $46, \mathrm{XX},-6,+\operatorname{der}(6), \mathrm{t}(6 ; 18)(18 \mathrm{qter} \rightarrow 18 \mathrm{q} 21:: 6 \mathrm{p} 24$ or $25 \rightarrow 6 \mathrm{qter})$ pat. 


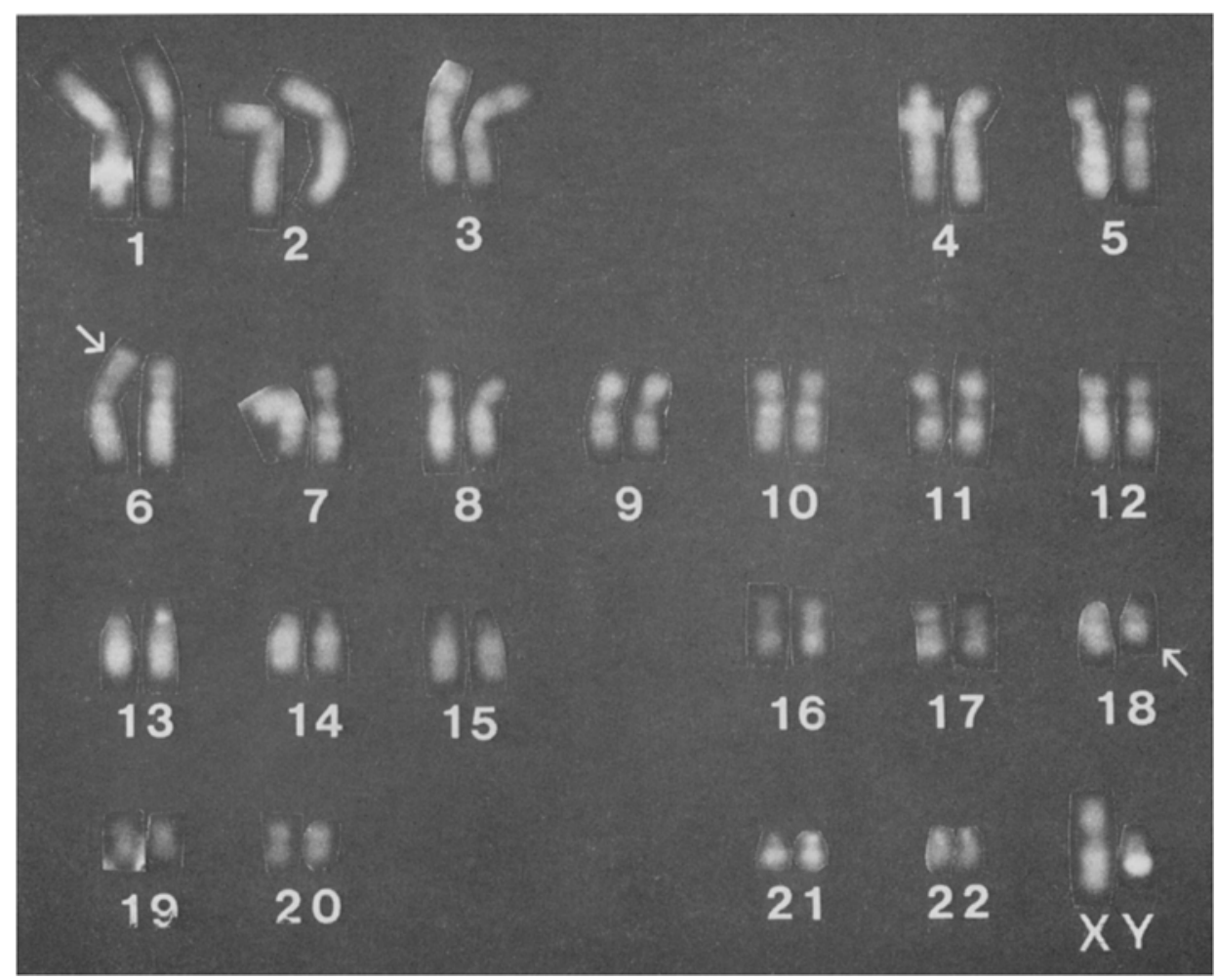

Fig. 3. Q-banded karyotype of the father.

\section{DISCUSSION}

In the trisomy 18 syndrome, the majority of reported cases are regular 18 trisomy but there are other subtypes such as partial trisomy (translocation trisomy), isochromosome, $+\mathrm{i}(18 \mathrm{p})$ and $+\mathrm{i}(18 \mathrm{q})$ (Miller et al., 1965), mosaicism and double chromosomal anomalies. In 1961 Van Wijk reported the first case of E trisomy resulting from a reciprocal translocation. In our case, the long arm of chromosome 18 was translocated to the short arm of chromosome 6. Partial 18 trisomy derived from the translocation involving chromosomes of $\mathrm{C}$ group is rare and only 5 cases have been reported, that is, $\mathrm{t}(6 ; 18)(\mathrm{p} ; \mathrm{q})$ Orye and van Caster, $1972 ; \mathrm{t}(6 ; 18)$ (q;q) Goto et al., 1973; ins(11;18) (p15;q11q21) Chudley et al., 1974; $\mathrm{t}(8 ; 18)(\mathrm{p} 232$; q123) Turleau and de Grouchy, 1977; t(12;18) (q24;q21) Fried et al., 1978.

Rohde et al. (1964) described that long arm trisomy was accompanied by failure to thrive, hypertonicity, mental retardation, flexion deformity of fingers and congenital heart diseases, while short arm trisomy had mental retardation, low set ears and micrognathia. Eriksson et al. (1971) speculated that the phenotype of 18 


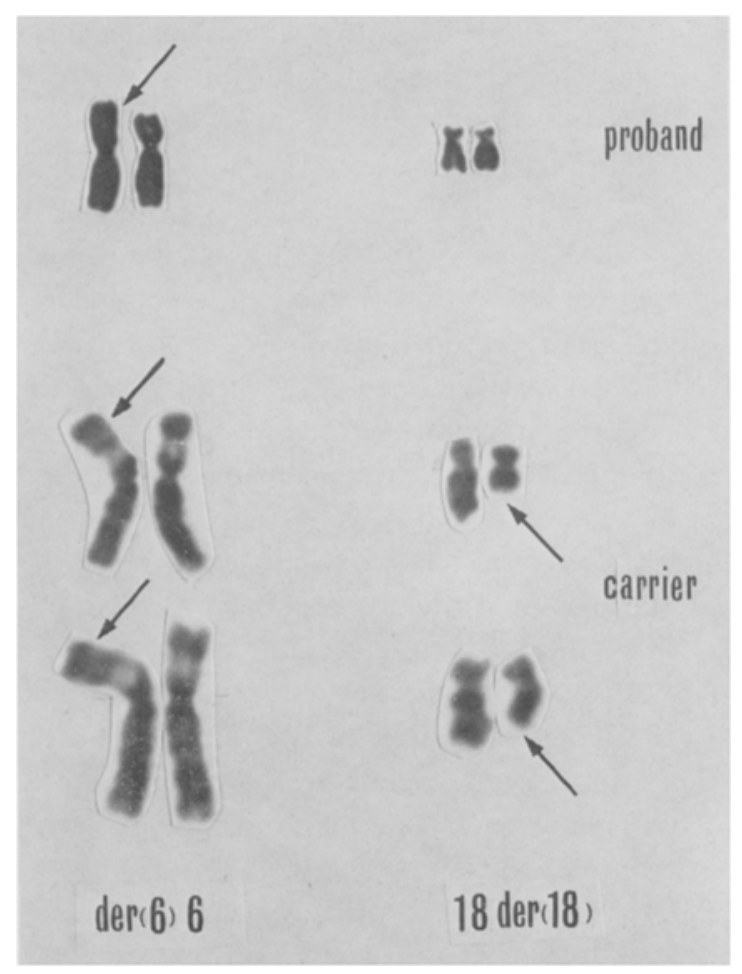

Fig. 4. Non-banded and banded partial karyotypes of the proband and her father (carrier). Arrows in the G-banded karyotypes of the carrier indicate breakage at the chromosome band $18 \mathrm{q} 21$ and reunion at the chromosome band $6 \mathrm{p} 24$ or $6 \mathrm{p} 25$, respectively.

trisomy is produced only when the long arm is completely triplicated. Since banding techniques have been introduced to identify chromosomes, several authors reported cases of 18 trisomy with the exact trisomic parts. Fried et al. (1978) described that trisomy for the distal one third of the long arm of chromosome 18 is not necessary to produce Edwards' syndrome.

Turleau and de Grouchy (1977) compared their own four cases of partial trisomy with several reported cases and concluded as follows: 1) Pure 18p trisomy does not have very characteristic phenotypes (Tangheroni et al., 1973; Condron et al., 1974; Nielsen et al., 1974; Balíček et al., 1976; Ogata et al., 1977). Common clinical features are psychomotor retardation, chubby face, low set ears, small triangular mouth, narrow high arched palate, flat nasal bridge, micrognathia, scoliosis, fairly normal dermatoglyphics and absence of distal flexion creases on the fingers. 2) Distal $18 \mathrm{q}$ trisomy which they called "trisomy 18qter," has the region $18 \mathrm{qter} \rightarrow 18 \mathrm{q} 22$ (Castel et al., 1975; Neu et al., 1976; Vianna-Morgante et al., 1976; Niazi et al., 1978). This syndrome is accompanied by anomalies such as high-bossed 
forehead, receding hair line, poorly indicated angles of the mandible, high arched palate, abnormally implanted teeth, normally set but posteriorly rotated ears with poorly folded helix, folds of redundant skin in the neck, narrow depressed chest, hernia, large hands with short fingers, abnormally implanted toes, typertonia of the limbs and excess of arches in dermatoglyphics. Visceral malformations are rare. The syndrome is accompanied by slight growth retardation, variable mental retardation and unimpaired life span. Compared to complete 18 trisomy, however, distal $18 \mathrm{q}$ trisomy syndrome does not show the following characteristic features of complete 18 trisomy which includes considerable growth retardation at birth, low set ears, clenched fists with overlapping fingers, severe inner organ malformation, narrow pelvis, rocker bottom feet and very short life span. They considered that the critical segment resulting in 18 trisomy syndrome locates on $18 \mathrm{q} 11$ and the region is responsible for most signs in this syndrome (Stern and Murch, 1975; Dziekanowska et al., 1976; Kameyama et al., 1977; Hodes et al., 1978; Fried et al., 1978).

There were a few cases which were not compatible with Turleau's postulation. Steele et al. (1974) reported two siblings in one family who had trisomy for the distal half of the long arm of chromosome 18. Although the q11 region was not triplicated, one of them had characteristic features of Edwards' syndrome. On the other hand, Chudley et al. (1974) reported three family members who did not show typical features in spite of triplication of the q11 region. However, it seems acceptable that q11 is the critical region in 18 trisomy syndrome.

The karyotype of the proposita was $46, X X,-6,+\operatorname{der}(6), t(18 q$ ter $\rightarrow 18 q 21::$ $6 \mathrm{p} 24$ or $25 \rightarrow 6 \mathrm{qter}$ )pat. According to Turleau's definition, the proposita belongs to the distal $18 \mathrm{q}$ trisomy syndrome because the chromosomal pattern was trisomic for $18 \mathrm{q}$ without the $\mathrm{q} 11$ region and she did not have characteristic features of 18 trisomy syndrome.

Subsequently, the mother became pregnant with the next child and amniocentesis was carried out. The chromosomal examination revealed balanced reciprocal translocation, being identical with the father's karyotype. The child was born phenotypically normal.

Acknowledgement We wish to thank Dr. Nakagome, Department of Human Genetics, National Institute of Genetics for his cordial advice.

\section{REFERENCES}

Abe, T., Morita, M., Misawa, S., Sawai, K., and Takeda, K. 1976. Fundamental studies on Gstaining procedures of human chromosome (in Japanese). Jap. J. Clin. Pathol. 24: 141-144.

Baliček, P., Žižka, J., and Lichý, J. 1976. An isochromosome of the short arms of the no. 18 chromosome in a mentally retarded girl. Clin. Genet. 9: 192-196.

Brodie, H.R., and Dallaire, L. 1962. The E syndrome (trisomy 17-18) resulting from a maternal chromosomal translocation. Can. Med. Assoc, J. 87: 559-561. 
Caspersson, T., Zech, L., Johansson, C., and Modest, E.J. 1970. Identification of human chromosomes by DNA-banding fluorescent agents. Chromosoma 30: 215-227.

Castel, Y., Rivière, D., Nawrocki, Th., Le Fur, J.M., and Toudic, L. 1975. Trisomie partielle 18q par translocation familiale $\mathrm{t}(18 \mathrm{q}-; 13 \mathrm{q}+)$. Lyon Méd. 233: 211-217.

Chesler, E., Freiman, I., Rosen, E., and Wilton, E. 1970. Congenital aneurysm of the membranous ventricular septum associated with partial trisomy E syndrome. Am. Heart J. 79: 805-810.

Chudley, A.E., Bauder, F., Ray, M., McAlpine, P.J., Pena, S.D.J., and Hamerton, J.L. 1974. Familial mental retardation in a family with an inherited chromosome rearrangement. J. Med. Genet. 11: 353-366.

Cohen, M.M., Finch, A.B., and Lubs, H.A. 1972. Trisomy 18 with an $E / G$ translocation [46,XY, $21-, t(21 q 18 q)+]$ identification of the component chromosomes by several laboratory techniques. Ann. Génét. 15: 45-49.

Condron, C.J., Cantwell, R.J., Kaufman, R.L., Brown, S.B., and Warren, R.J. 1974. The supernumerary isochromosome 18 syndrome $(+18$ pi). In: Birth Defects: Original Article Series $X$, No.10, pp. 36-42.

Dziekanowska, D., Dziuba, P., and Sobańsky, T. 1976. The trisomy 18 syndrome with an E/G translocation. Hum. Genet. 31: 347-349.

Edwards, J.H., Harnden, D.G., Cameron, A.H., Crosse, V.M., and Wolf, O.H. 1960. A new trisomic syndrome. Lancet 1: 787-789.

Eriksson, B., Fraccaro, M., Hultén, M., Lindsten, J., Thorén, C., and Tiepolo, L. 1971. Structural abnormalities of chromosome $18 \mathrm{II}$-two familial translocations, B/18 and $16 / 18$, ascertained through unbalanced forms. Ann. Génét. 14: 281-290.

Freiman, I. and Wilton, E. 1967 . Trisomy 16-18 in the Bantu. S. Afr. Med. J. 10: 558-561.

Fried, K., Bar-Yochai, A., Rosenblatt, M., and Mundel, G. 1978. Partial 18 trisomy (with 47 chromosomes) resulting from a familial maternal translocation. $J$. Med. Genet. 15: 76-78.

Gagnon, J., Archambault, L., Laberge, É., and Katyk-Longtin, N. 1963. Trisomie partille 18 par insertion ou translocation 4/18. Union Méd. Can. 92: 311-319.

Gleissner, M., Schwanitz, G., and Rott, H.D. 1970. Partielle Trisomie E18 (E18q-) als Folge einer balancierten Translokation D/E bei der Mutter. Monatsschr. Kinderheilkd. 118: 441444.

Goto, A., Komiya, H., and Matsui, I. 1973. 18 trisomy syndrome (in Japanese). J. Pediatr. Pract. 36: 935-945.

Hecht, F., 'Bryant, J., Arakaki, D., Kaplan, E., and Gentile, G. 1963. Trisomy-18 syndrome due to de-novo translocation. Lancet 1:114.

Hodes, M.E., Cole, J., Palmer, C.G., and Reed, T. 1978. Clinical experience with trisomies 18 and 13. J. Med. Genet. 15: 48-60.

Jenkins, E.C., Weed, R.G., and Sandstrom, M.McH. 1974. An additional case of partial trisomy 18. Ann. Génét. 17: 45-48.

Kameyama, J., Tsurusawa, M., Nakano, H., Shimizu, S., Okuda, R., Morita, M., and Abe, T., 1977. Trisomy for the long arm of the chromosome 18 due to de novo 18/21 translocation. Jap. J. Hum. Genet. 22: 11-15.

Meyer-Robisch, M. and Schwanitz, G. 1967. Familiäre D/E-Translokation. Acta Genet. Med. Gemellol. 16: 365-375.

Miller, J.Q., Rostafinski, M.J., and Hyde, M.S. 1965. A defective extra chromosome associated with clinical 17-18 trisomy syndrome. Pediatrics 36: 135-138.

Misawa, S., Takino, T., Sugishima, K., and Abe, T. 1975. Quinacrine-banding analysis of the Philadelphia chromosome from five patients with chronic myelogenous leukemia. Acta Haematol. Jap. 38: 307-310.

Neu, R.L., Ortega, C.C., Barg, G.A., Pinto, W., Gardner, L.I., Howell, W.M., and Denton, T.E. 1976. Inclusion of satellites in an 18/21 translocation chromosome shown by ammoniacal- 
silver staining (sat-banding) in case of partial trisomy 18. J. Med. Genet. 13: 520-522.

Niazi, M., Coleman, D.V., and Saldaña-Garcia, P. 1978. Partial trisomy 18 in a family with a translocation $(18 ; 21)$ (q21;q22). J. Med. Genet. 15: 148-151.

Nielsen, J., Hreidarsson, A.B., Berggreen, S., Ried, E., Tsuboi, T., and Saldaña-Garcia, P. 1974. A mentally retarded male with karyotype 47,XY,+mar=?i(18p). Ann. Génét. 17: 129-133.

Ogata, K., Iinuma, K., Kamimura, K., Morinaga, R., and Kato, J. 1977. A case report of a presumptive $+\mathrm{i}(18 \mathrm{p})$ associated with serum IgA deficiency. Clin. Genet. 11: 184-188.

Orye, E., and Van Caster, A. 1972. Familiaire partiële trisomie 18. Acta Paediatr. Belg. 26: $41-52$.

Rohde, R.A., Lee, A., and Sapin, S. 1963. A new trisomy-translocation chromosome (long arm E/E). Lancet. 2: 1309-1310.

Rohde, R.A., Hodgman, J.E., and Cleland, R.S. 1964. Multiple congenital anomalies in the Eltrisomy (group 16-18) syndrome. Pediatrics 33: 258-270.

Rudd, N.L. and Lamarche, P.H. 1971. Gene deletion and duplication effects on phenotype and gamma globulin levels. J. Med. Genet. 8: 97-106.

Steele, M.W., Pan, S., Mickell, J., and Senders, V. 1974. Trisomy for the distal half of the long arm of chromosome No.18. J. Pediatr. 85: 827-829.

Stern, L.M., and Murch, A.R., 1975. Pseudohermaphroditism with clinical features of trisomy 18 in an infant trisomic for parts of chromosomes 16 and $18: 47, \mathrm{XY}$,der(18), t(16;18) (p12;q11) mat. J. Med. Genet. 12: 305-307.

Tangheroni, W., Cao, A., and Furbetta, M. 1973. Multiple anomalies associated with an extra small metacentric chromosome: modified Giemsa stain results. Humangenetik 18: 291-295.

Turleau, C., and de Grouchy, J. 1977. Trisomy 18qter and trisomy mapping of chromosome 18. Clin. Genet. 12: 361-371.

Uchida, I.A., Wang, H.C., Laxdal, O.E., Zaleski, W.A., and Duncan, B.P. 1964. Cytogenetics 3: 81-96.

Valdmanis, A., Pearson, G., Siegel, A.E., Hoeksema, R.H., and Mann, J.D. 1967. A pedigree of 4/18 translocation chromosomes with type and countertype partial trisomy and partial monosomy for chromosome 18. Ann. Génét. 10: 159-166.

Van Wijk, J.M.A., Tijdink, G.A.J., and Stolte, L.A.M. 1961. A case of partial trisomy. Lancet 2: 1454 .

Vianna-Morgante, A.M., Nozaki, M.J., Ortega, C.C., Coates, V., and Yamamura, Y. 1976. Partial monosomy and partial trisomy 18 in two offspring of carrier of pericentric inversion of chromosome 18. J. Med. Genet. 13: 366-370. 